\title{
PENGARUH KUALITAS LAYANAN TERHADAP KOMITMEN AFEKTIF, KOMITMEN NORMATIF, KOMITMEN KONTINUAN SERTA LOYALITAS NASABAH DEBITUR PADA PT. BANK KALBAR DI KALIMANTAN BARAT
}

\author{
Nur Afifah \\ Dosen Fakultas Ekonomi Universitas Tanjungpura Pontianak \\ afifahnur_fe@yahoo.com
}

\begin{abstract}
Abstrak
Perusahaan perbankan saat ini harus berupaya semaksimal mungkin untuk menciptakan pengalaman pelanggan terhadap kualitas layanan, dikarenakan memiliki dampak terhadap hasil hubungan pelanggan (Customer Relationship). Salah satu kunci sukses dalam industri perbankan adalah dibutuhkannya interaksi personal dalam bentuk implementasi strategi relationship marketing (pemasaran relasi), hal ini dikarenakan sifat layanan yang tidak berwujud dan tidak bisa dipisahkan dari penyedia layanan dengan demikian lembaga perbankan harus peduli dengan pengembangan dan pengelolaan hubungan dengan pelanggan.

Tujuan studi ini mengkaji pengaruh kualitas layanan terhadap komitmen afektif, komitmen normatif, komitmen kontinuan serta loyalitas nasabah debitur pada PT. Bank Kalbar di Kalimantan Barat. Hal ini di karenakan, kualitas layanan selain memiliki efek pada komitmen hubungan, kualitas layanan yang disampaikan dapat menjadi motivasi dalam diri nasabah debitur untuk melanjutkan hubungan dengan perusahaan perbankan. Komitmen pelanggan dipandang sebagai faktor kunci dalam retensi pelanggan dan loyalitas, sedangkan kualitas layanan umumnya dipandang sebagai struktur utama yang mendorong loyalitas pelanggan. Dalam studi ini, ukuran kualitas layanan diantaranya, adalah; kualitas interaksi (interaction quality), kualitas lingkungan (environment quality) dan kualitas hasil akhir (outcome quality). Adapun komitmen pelanggan, dalam hal ini dibedakan menjadi tiga yaitu, komitmen afektif, komitmen normatif dan komitmen kontinuan.

Sampel dalam studi ini adalah 126 nasabah debitur PT. Bank Kalbar di Kalimantan Barat yang menggunakan kredit untuk kegiatan usaha dan minimal satu kali transaksi peminjaman, dengan menggunakan teknik cluster sampling untuk menentukan kantor cabang dikarenakan lokasi PT. Bank Kalbar menyebar secara geografis serta proporsional sampel dalam menetapkan jumlah responden pada masing-masing cabang. Teknik analisi data dengan Structural Equation Modeling (SEM). Hasil study mengatakan bahwa kualitas layanan berpengaruh signifikan terhadap komitmen afektif, komitmen normatif, dan komitmen kontinuan, dan kualitas layanan berpengaruh signifikan terhadap loyalitas, serta komitmen afektif, komitmen normatif dan komitmen kontinuan berpengaruh signifikan terhadap loyalitas nasabah debitur PT. Bank Kalbar di Kalimantan Barat.
\end{abstract}

Key word: kualitas layanan, komitmen afektif, komitmen normatif, komitmen kontinuan, loyalitas nasabah debitur. 
Nur Afifah

\section{LATAR BELAKANG}

Adanya kondisi persaingan yang sangat kompetitif saat ini, kualitas layanan (service quality) secara luas diakui sebagai persyaratan penting dari suatu perusahaan, hal ini sesuai dengan pendapat (Voss et al., 2004; Vilares and Coehlo, 2003; Van der weile et al., 2002) bahkan kualitas layanan sebagai salah satu strategi kompetitif (Rosen et al., 2003) yang sangat penting untuk meningkatkan profitabilitas perusahaan dan kelangsungan hidup perusahaan. Bahkan menurut Siddiqi Kazi Omar (2011), kualitas layanan telah menarik para peneliti pada bisnis perbankan selama dekade terakhir di bidang perbankan bahkan masih dipandang sebagai kebutuhan yang sangat relevan untuk melakukan eksplorasi lebih mendalam terhadap dimensidimensi kualitas layanan yang benar-benar mampu mengakomodasi ciri-ciri spesifik operasional usaha perbankan.

Pelanggan harus tetap di jaga dan dipertahankan agar tidak berpaling ke perusahaan lain. Bank harus dapat menciptakan strategi pemasaran yang mampu memberi sentuhan layanan personal, terjadi interaksi yang meliputi serangkaian moment of truth antara pelanggan dan penyedia jasa selama proses penyampaian jasa. Oleh karena itu, agar tujuan-tujuan seperti yang telah diuraikan tersebut terwujud, maka perusahaan harus berusaha terus menerus memberikan layanan yang berkualitas dan menjalin hubungan jangka panjang yang saling menguntungkan dengan para nasabahnya dengan berusaha menciptakan komitmen afektif, komitmen normatif, dan komitmen kontinuan sehingga diharapkan para nasabah tersebut bersedia menjalin hubungan jangka panjang dan memiliki tingkat loyalitas yang tinggi dengan perusahaan.

Penelitian ini menggabungkan dua studi, yakni studi tentang kualitas layanan dan studi tentang pemasaran relasi dalam hal ini adalah komitmen pelanggan dalam industri jasa perbankan. Hal ini dikarenakan selain efeknya pada komitmen hubungan, kualitas layanan yang disampaikan dapat menjadi motivasi dalam diri nasabah untuk melanjutkan hubungan. Mendukung pernyataan tersebut Morgan and Hunt (1994); Gruen et al. (2000) dalam Fullerton (2004), mengemukakan komitmen pelanggan dipandang sebagai faktor kunci dalam retensi pelanggan dan loyalitas, sedangkan kualitas layanan umumnya dipandang sebagai struktur utama yang mendorong loyalitas pelanggan (Cronin and Taylor, 1992; Zeithaml et al., 1999).

\section{TINJAUAN PUSTAKA}

\section{Kualitas Layanan}

Sebuah bank dapat membedakan dirinya dari pesaing dengan menyediakan layanan yang berkualitas tinggi. Hal ini dikarenakan kualitas layanan adalah salah satu faktor keberhasilan kritis yang mempengaruhi daya saing organisasi. Menurut Angur and Natrjan dalam Sudhahar J.Clement et al. (2006) mengemukakan bahwa persepsi kualitas pelayanan berperan penting terhadap industri jasa yang memiliki keterlibatan tinggi seperti bank.

Pelanggan mengevaluasi kinerja bank terutama didasarkan pada kontak pribadi mereka dan interaksi (Gonross, 1990). Menurut Beerli et al. (2004) dalam industri keuangan seperti perbankan, dimana lingkungan yang kompetitif dan dinamis dan layanan yang ditawarkan sangat kompleks, adalah penting untuk mengenali pentingnya orientasi pelanggan sesuai dengan prinsip-prinsip dasar pemasaran relasional. Hal ini sejalan dengan pendapat (Liang and Wang, 2007), dalam rangka untuk mempertahankan pelanggan benar-benar loyal, perusahaan perlu mengembangkan kualitas hubungan dengan pelanggan (Jones and Taylor, 2007). Pada industri jasa seperti industri perbankan sangat penting mengembangkan konsep pemasaran hubungan pelanggan. 


\section{Jurnal Manajemen Teori dan Terapan Tahun 5. No. 2. Agustus 2012}

Maka dalam penelitian ini, ditetapkan dimensi dan atribut penelitian yang menggabungkan dimensi kualitas layanan yang dikemukakan oleh Brady and Cronin (2001) serta dimensi SERVQUAL (Parasuraman et al., 1988). Hal ini dikarenakan bahwa konsep kualitas pelayanan yang dikembangkan oleh Brady and Cronin (2001) sangat mendukung penelitian ini karena menggunakan pendekatan relasional, sedangkan konsep kualitas layanan yang dikembangkan oleh Parasuraman et al. (1998) dipilih dengan dasar pertimbangan mewakili aspek operasional dari bisnis perbankan, yaitu reliable, responsiveness dan assurance pada SERVQUAL. Pengukuran kualitas layanan dalam studi ini dibagi menjadi tiga indikator diantaranya; kualitas interaksi (Brady and Cronin, 2001), merupakan persepsi nasabah sebagai hasil penilaian terhadap kualitas interaksi antara karyawan dengan nasabah pada saat berinteraksi dalam memberikan layanan, dalam hal ini adalah bagaimana cara staf layanan bersikap, berperilaku terhadap nasabah serta keahlian yang dimiliki staf layanan yang dapat memenuhi kebutuhan nasabah debitur kredit usaha kecil.

Kualitas lingkungan fisik (Brady and Cronin, 2001), merupakan persepsi nasabah sebagai hasil penilaian terhadap fasilitas fisik diantaranya lokasi bank, tempat parkir yang aman serta suasana ruangan layanan yang nyaman. Kualitas hasil akhir (Brady and Cronin, 2001; Gronroos, 1990), merupakan persepsi nasabah sebagai hasil penilaian terhadap setiap proses layanan yang diberikan oleh PT. Bank Kalbar dalam hal kecepatan layanan (responsiveness), jaminan rasa aman nasabah debitur dalam melakukan transaksi (assurance) serta sistim administrasi yang diterapkan pada kredit usaha kecil yang ditawarkan mudah dimengerti oleh nasabah debitur (reliability).

\section{Komitmen Afektif}

Para pihak yang terlibat dalam hubungan komitmen afektif karena mereka saling menyukai hubungan tersebut. Komitmen afektif dalam pemasaran relasi (relationship marketing) seperti yang dikemukakan oleh banyak penulis dibidang ini (Garbarino and Johnson, 1999; Doney and Cannon, 1997; Morgan and Hunt, 1994; Heide and John; 1992), yaitu merujuk pada pembagian nilai (share values), kepercayaan (beliefs), kemurahan hati (benevolence), dan hubungan baik (relationalism), sedangkan menurut Gruen dalam Tim Jones and Gavin L. Fox, (2010) mendefinisikan komitmen afektif adalah tingkat keterikatan secara psikologis dengan organisasi berdasar seberapa baik perasaan mengenai orgniasasi. Definisi ini hampir sama dengan definisi dari komitmen afektif dalam hubungan karyawan dengan organisasi (Allen and Mayer, 1990; O'Reilly and Chatman dalam Fullerton, 2000). Jadi perkembangan ikatan sosial antara pelanggan dan penyedia merupakan tahap penting dalam pengembangan komitmen dalam hubungan pemasaran.

Menurut Johnson et al. (2008) Komitmen afektif dalam hubungan antara nasabah dengan bank, mengacu pada ikatan emosional pelanggan kepada perusahaan perbankan serta rasa memiliki terhadap perusahaan perbankan. Hal ini menggambarkan intensitas dan keterlibatan pelanggan dalam hubungan layanan dimana nasabah tetap bertahan menjadi nasabah perusahaan perbankan dikarenakan mitra pertukaran memiliki kredibilitas, dan selalu memenuhu janji-janji yang diberikan (Bitner, 1995). Kredibilitas sebagai unsur kepercayaan yang diidentifikasi dari kualitas layanan yang diberikan oleh lembaga perbankan dengan nasabahnya (Parasuraman et al., 1988). Hal ini sejalan dengan pendapat Heida and John (1992) yang menyatakan bahwa kredibilitas yang dimiliki oleh perusahaan akan menentukan interaksi antara karyawan dengan nasabah perbankan sehingga komitmen afektif dalam hubungan pemasaran mencakup sejauh mana pihak-pihak percaya bahwa mereka memiliki nilai- nilai bersama (Morgan and Hunt, 1994). Nilai bersama adalah sejauh mana mitra memiliki 
Nur Afifah

keyakinan umum tentang perilaku, tujuan dan kebajikan penting atau tidak penting, tepat atau tidak tepat (Morgan and Hunt, 1994).

\section{Komitmen Normatif}

Komitmen Normatif bertahan dalam pemasaran relasional ketika pelanggan merasa sebagai bagian dari tanggung jawab perusahaan. Menurut Bagozi (1993) Unsur komitmen ini dapat dijelaskan dari konsep timbal balik (reciprocity), dan nilai- nilai bersama (Fournier et al.1998), serta legitimasi. Unsur-unsur komitmen normatif tersebut merupakan konstruk menyeluruh yang menjadi peyebab tumbuhnya rasa berbagi tanggung jawab sebagai pendorong antara konsumen dengan perusahnaan dalam menjalin hubungan.

Menurut Gruen et al., 2000 dalam Tim Jones and Gavin L. Fox (2010), meyatakan bahwa dalam kaitannya dengan komitmen normatif, segala sesuatu yang mendorong anggota untuk tetap berada dan memberikan sumbangan pada keberadaan suatu orgnisasi, baik materi maupun non materi adalah adanya kewajiban moral yang mana seseorang akan merasa tidak nyaman dan bersalah jika tidak melakukan sesuatu. Jadi komitmen normatif merupakan kekuatan yang mengikat seorang konsumen secara psikologis terhadap penyedia layanan untuk memelihara hubungan dengan orgnaisasi, sehingga konsumen merasa memiliki kewajiban untuk tidak berpindah kepada perusahaan lain.

Pada dasarnya, pelanggan yang berkomitmen untuk hubungan normatif terus melakukan bisnis dengan perusahaan karena secara moral, untuk melakukannya. Dalam penelitian ini dimana nasabah merasa memiliki nilai-nilai bersama sangat tinggi, merasa keharusan untuk tetap menjadi nasabah dalam perusahaan perbankan sehingga pada saat yang sama konsumen mungkin merasa berkewajiban untuk melakukan bisnis dengan bank tertentu sehingga terus mendukung kegiatan masyarakat.

Menurut Bagozi (1993) berpendapat bahwa timbal balik merupakan masalah yang berfokus pada hubungan pemasar. Pada pertukaran, kualitas layanan dapat membangkitkan perasaan timbal balik karena pelanggan merasa terdorong untuk melakukan perbuatan baik dengan komitmen. Oleh karena itu agar pelanggan memiliki komitmen normatif maka perusahaan jasa harus selalu berupaya menyediakan jasa sesuai dengan harapan pelanggan, tidak hanya sekedar janji-janji tetapi diaktualisasikan dengan memberikan pelayanan yang dapat membuat nasabah puas.

\section{Komitmen Kontinuan}

Menurut Bendapudi and Berry (1997); Gundlach, Achrol and Mentzer, (1995); Heide and John (1992), menyatakan komitmen kontinuan dalam pemasaran relasional berakar dari biaya peralihan (switching cost), pengorbanan (sacrifice), dan ketergantungan (dependence). Selain itu komitmen kontinuan dibangun berdasarkan pada biaya peralihan dan kelangkaan alternatif (Allen and Meyer, 1990; Mathieu and Dennis, 1992; O'Reilly and Chatman, 1986), dengan kata lain pelanggan dapat melakukan komitmen dengan perusahaan jika mereka merasa pada akhir hubungan tersebut memang diperlukan adanya pengorbanan ekonomi maupun sosial.

Menurut Gruen et al., dalam Tim Jones and Gavin L. Fox (2010) komitmen kontinuan, dapat didefinisikan sebagai sejauh mana suatu pelanggan secara psikologis terikat pada layanan organisasi yang dihubungkan dengan biaya yang dikeluarkan karena adanya hubungan tersebut, dalam kaitan dengan ini konsumen akan mengkalkulasi manfaat dan pengorbanan atas keterlibatan dalam atau menjadi anggota suatu organisasi. Komitmen dihasilkan dari analisis ekonomi dari biaya dan manfaat dengan membuat komitmen. 


\section{Jurnal Manajemen Teori dan Terapan Tahun 5. No. 2. Agustus 2012}

\section{Loyalitas Nasabah}

Menurut Liu et al. (2003) dan Slater (1997) ukuran loyalitas terdiri dari; niat untuk melakukan pembelian ulang (repeat purchase), niat untuk mengatakan hal-hal positif tentang perusahaan pada orang lain (positif remarks), dan niat untuk merekomendasikan perusahaan kepada orang lain (recommend to others), serta niat memberikan informasi personal kepada perusahaan (giving personal information), sedangkan menurut (Zeithaml et al., 1996; Bloemer Josee and Gaby Odekerken-Schoroder; 2007) berkenaan dengan niat perilaku dalam pemasaran jasa, ukuran loyalitas terdiri dari : Word of Mouth (komunikasi dari mulut ke mulut), Purchase Intention (niat pembelian), Price Insensitivity (ketidakpekaan harga) dan, Complaining (keluhan). Sedangkan Fullerton and Taylor (2000), melihat loyalitas dalam hubungan antara kualitas jasa dengan sikap (perilaku) seperti re-purchase, advocacy dan price sensitivity.

Pengukuran loyalitas nasabah dalam studi ini menggunakan tiga indikator mengacu indikator yang dikembangkan oleh Zeithaml et al. (1996) dan Bloemer Josee and Gaby OdekerkenSchoroder (2007) serta Liv et al. (2003) dan Slater (1997) digunakan satu indikator.

\section{PENGEMBANGAN HIPOTESA}

Kualitas layanan merupakan penilaian pelanggan dari keseluruhan tingkat layanan yang diberikan oleh perusahaan atau organisasi (Parasuraman et al., 1988), sehingga penilaiannya didasarkan pada persepsi selama pertemuan layanan (Bitner et al., 1990; Johns, 1997). Apa yang terjadi selama proses interaksi akan sangat mempengaruhi terhadap jasa yang dipersepsikan oleh pelanggan. Hal ini sejalan dengan pendapat Meyer and Schwager; Schmitt; Shaw, dalam Lemke Fred, Moira Clark and Hugh Wilson (2010) yang menyatakan bahwa jasa juga merupakan suatu komoditas dan tuntutan konsumen kontemporer tidak sekedar kompeten dalam layanan, tetapi mendapatkan pengalaman (experience quality) yang "menarik, kuat, menarik dan mengesankan" Gilmore and Pine (2002;10). Oleh karena itu, agar penjualan jasa suatu bank lebih unggul dari pesaingnya, maka salah satu cara agar nasabah tetap bertahan dan menjadi nasabah yang loyal adalah dengan memberikan layanan yang berkualitas yang dapat memenuhi harapan nasabah.

Hasil penelitian Bloemar, Ruyter and Peeters, (1998); Liu, Sudharshan and Hamer (2000); Caruana (2002); Fullerton and Taylor (2002); Song and Zinkhan (2003); Dean M. Alison (2010); Jones Tim et al. (2010) menemukan bahwa kualitas layanan berpengaruh signifikan terhadap loyalitas nasabah.

Selain efeknya pada komitmen hubungan, kualitas layanan yang disampaikan dapat menjadi motivasi dalam diri nasabah untuk melanjutkan hubungan. Mendukung pernyataan tersebut Morgan and Hunt (1994); Gruen et al. (2000) dalam Fullerton (2004), mengemukakan komitmen pelanggan dipandang sebagai faktor kunci dalam retensi pelanggan dan loyalitas, sedangkan kualitas layanan umumnya dipandang sebagai struktur utama yang mendorong loyalitas pelanggan (Cronin and Taylor, 1992; Zeithaml et al., 1999). Oleh karena itu sangatlah berarti untuk menggabungkan dua studi tersebut, yakni studi tentang kualitas layanan dan studi tentang pemasaran relasi dalam hal ini adalah komitmen pelanggan dalam industri jasa perbankan. Berdasarkan hal tersebut, empat hipotesa berikut diajukan:

H1: Kualitas layanan berpengaruh signifikan terhadap loyalitas nasabah debitur PT. Bank Kalbar di Kalimantan Barat 
H2: Kualitas layanan berpengaruh signifikan terhadap komitmen afektif nasabah debitur PT. Bank Kalbar di Kalimantan Barat.

H3: Kualitas layanan berpengaruh signifikan terhadap komitmen normatif nasabah debitur PT. Bank Kalbar di Kalimantan Barat.

H4: Kualitas layanan berpengaruh signifikan terhadap komitmen kontinuan nasabah debitur PT. Bank Kalbar di Kalimantan Barat.

Berbagai penelitian yang telah di lakukan mengenai konsep komitmen, loyalitas dalam hubungannya dengan kualitas jasa secara empirik menunjukkan hasil yang beragam (Fullerton and Taylor, 2000; Fullerton, 2005; Cater Barbara, 2009; Jones Tim et al., 2010). Untuk itu peneliti tertarik melakukan pengujian dari segi pengukuran instrumen kualitas jasa dengan menggunakan konsep kualitas jasa menurut Brady and Cronin (2001) serta Parasuraman et al. (1988), tiga komitmen yaitu (komitmen afektif, komitmen kontinuan serta komitmen normatif) dan loyalitas konsumen pada industri jasa yaitu Perbankan. Pengujian pada tingkat pengukuran ini perlu dilakukan karena adanya perbedaan dari segi karakteristik konsumen yang berbeda, termasuk pula perbedaan jasa yang ditawarkan. Selain itu pula, perbedaan latar belakang budaya, sosial. dan tingkat ekonomi konsumen akan memberikan kecenderungan perilaku yang berbeda.

Komitmen merupakan landasan dalam pemasaran hubungan dan menjadi konstruk dalam pemasaran serta sebagai pergerakan filosofis bisnis dari pandangan transaksional yang hanya sekedar pertukaran ke pandangan relasi yang berusaha untuk mempertahankan pelanggan. Para ahli pemasaran mengakui bahwa komitmen memiliki beberapa komponen dan telah mengadopsi dari literatur perilaku organisasi, Allen and Meyer (1994), dari komitmen organisasi untuk studi komitmen pelanggan (Jones Tim et al., 2010; Barbara Cater and Vesna Zabkar, 2009; Fullerton, 2005; Venetis Karin and Pervez N. Ghauri, 2004; Bansal et al., 2004; Fullerton, 2000; Gundlach et al., 1995; Gruen et al., 2000; Harrison-Walker, 2001). Penelitian dalam bidang pemasaran telah menggeneralisasi tentang tiga hal dalam membangun komitmen, diantaranya adalah: 1. Orang menjadi berkomitmen untuk hal yang berbeda, dengan kata lain komitmen diarahkan pada target, 2. Orang mengalami komitmen dalam bentuk yang berbeda, dan 3. Dimensi-dimensi yang berbeda dari komitmen menghasilkan efek yang berbeda pada berbagai hasil hubungan yang terkait (Gruen et al., 2000; Garbarino and Johnson, 1999).

Oleh karena itu beberapa penelitian dalam bidang pemasaran saat ini, diantaranya Beth Davis et al. (2009); Alison M. Dean (2009); Fullerton (2005); Venetis and Ghauri (2004); Harvir S Bansal et al. (2004); Fullerton (2003); Gilliland and Bello (2002); Harrison-Walker (2001), menyatakan bahwa komitmen pelanggan memiliki dua komponen yaitu komitmen afektif dan komitmen kontinuan. Akan tetapi (Jones Tim et al. 2010; Cater Barbara and Vesna Zabkar, 2009; Bloemer Josee et al., 2007; Cater Barbara, 2007; Gruen et al., 2000) telah memasukkan komitmen normatif dalam hubungannya dengan komitmen pelanggan, yang mana dalam penelitian pemasaran yang memasukkan komitmen normatif relatif masih sedikit, hal ini yang mendorong peneliti untuk melakukan studi lebih lanjut.

Beberapa hasil penelitian yang menjelaskan hubungan antara loyalitas terhadap komitmen diantaranya Henning-Thurau et al. (2002); Josee Bloemer (2003); Boonajseve (2005); Fullerton (2005); Ruben (2007); Josee Blomer (2007); Dean (2007); Cater (2009); Davis (2009); Jones Tim et al. (2010).Untuk itu, hipotesa berikut diajukan.

H5: Komitmen afektif berpengaruh signifikan terhadap loyalitas nasabah debitur PT. Bank Kalbar di Kalimantan Barat. 
H6: Komitmen normatif berpengaruh signifikan terhadap loyalitas nasabah debitur PT. Bank Kalbar di Kalimantan Barat.

H7: Komitmen kontinuan berpengaruh signifikan terhadap loyalitas nasabah debitur PT. Bank Kalbar di Kalimantan Barat.

\section{METODOLOGI PENELITIAN}

Studi ini menggunakan indikator dari beberapa sumber. Untuk mengukur kualitas layanan, digunakan 3 indikator yang dikembangkan oleh (Brady and Cronin, 2001). Sedangkan untuk mengukur komitmen afektif digunkana 4 indikator yang dikembangkan oleh Allen and Mayer (1990); Josee Bloemer and Gaby Odekerken (2007); Jones Tim and Gavin L. Fox (2010). Untuk mengukur komitmen normatif digunkana 4 indikator yang dikembangkan oleh Allen and Mayer (1990); Josee Bloemer and Gaby Odekerken (2007); Jones Tim and Gavin L. Fox (2010). Sedangkan untuk mengukur komitmen kontinuan digunkana 3 indikator yang dikembangkan oleh Allen and Mayer (1990); Josee Bloemer and Gaby Odekerken (2007); Jones Tim and Gavin L. Fox (2010).

Jumlah sampel dalam studi ini sebanyak 126 responden nasabah debitur PT. Bank Kalbar di Kalimantan Barat yang menggunakan kredit untuk kegiatan usaha dan minimal satu kali transaksi peminjaman, dengan menggunakan teknik cluster sampling untuk menentukan kantor cabang dikarenakan lokasi PT. Bank Kalbar menyebar secara geografis serta proporsional sampel dalam menetapkan jumlah responden pada masing-masing cabang. Alat analisis yang digunakan adalah Structural Equation Modeling (SEM) Amos Versi 18.

\section{ANALISA}

Tabel 1. HASIL PENGUJIAN HIPOTESIS

\begin{tabular}{|c|c|c|c|c|}
\hline Variabel & Koefisien & C.R. & Prob. & Keterangan \\
\hline $\begin{array}{ll}\text { Kualitas Layanan } & \left(X_{1}\right) \rightarrow \\
\text { Loyalitas Nasabah }\left(Y_{4}\right) & \end{array}$ & 0,238 & 1,988 & 0,047 & Signifikan \\
\hline $\begin{array}{ll}\text { Kualitas Layanan } & \left(X_{1}\right) \rightarrow \\
\text { Komitmen Afektif }\left(Y_{1}\right) & \\
\end{array}$ & 0,286 & 2,009 & 0,045 & Signifikan \\
\hline $\begin{array}{l}\text { Kualitas Layanan }\left(X_{1}\right) \rightarrow \\
\text { Komitmen Normatif }\left(Y_{2}\right)\end{array}$ & 0,324 & 2,119 & 0,028 & Signifikan \\
\hline $\begin{array}{l}\text { Kualitas Layanan }\left(X_{1}\right) \rightarrow \\
\text { Komitmen Kontinuan }\left(Y_{3}\right)\end{array}$ & 0,118 & 2,835 & 0,004 & Signifikan \\
\hline $\begin{array}{l}\left.\text { Komitmen Afektif (Y } Y_{1}\right) \rightarrow \\
\text { Loyalitas Nasabah }\left(Y_{4}\right)\end{array}$ & 0,266 & 2,858 & 0,004 & Signifikan \\
\hline $\begin{array}{l}\text { Komitmen Normatif } \\
\text { Loyalitas Nasabah }\left(Y_{4}\right)\end{array}$ & 0,056 & 2,006 & 0,045 & Signifikan \\
\hline $\begin{array}{ll}\text { Komitmen Kontinuan } & \left(Y_{3}\right) \rightarrow \\
\text { Loyalitas Nasabah }\left(Y_{4}\right) & \end{array}$ & 0,310 & 4,147 & 0,000 & Signifikan \\
\hline
\end{tabular}

Hipotesis 1 : Kualitas Layanan $\left(X_{1}\right)$ Berpengaruh Signifikan Terhadap Loyalitas Nasabah Debitur PT. Bank Kalbar di Kalimantan Barat $\left(\mathrm{Y}_{4}\right)$. 
Hasil pengujian koefisien jalur (Tabel 1) menunjukkan bahwa kualitas layanan berpengaruh signifikan terhadap loyalitas nasabah dengan arah positif sebesar 0,238 dengan probabilitas signifikansi (p) sebesar 0,047 yang lebih kecil dari taraf signifikansi (a) yang ditentukan sebesar 0,05 . Hal ini berarti bahwa hipotesis pertama dalam studi ini yang menyatakan bahwa kualitas layanan berpengaruh signifikan terhadap loyalitas nasabah debitur PT. Bank Kalbar di Kalimantan Barat terbukti kebenarannya.

Hasil studi ini sejalan dengan hasil penelitian yang dilakukan oleh Crauna (2002); Alison M. Dean (2007); Jamal Ahmad and Kyriaki Anatasiadou (2009); Madder et al. (2010) serta Jones Tim et al. (2010) yang mana hasil studinya menjelaskan bahwa kualitas layanan berpengaruh signifikan terhadap loyalitas nasabah. Namun, perlu ditegaskan bahwa terdapat perbedaan antara studi ini dengan penelitian yang dilakukan oleh Crauna (2002);Jamal Ahmad and Kyriaki Anatasiadou (2009); Madder et al. (2010) serta Jones Tim et al. (2010) yaitu kualitas layanan dalam studi ini berfokus pada kualitas layanan yang berorientasi pada konsep pemasaran relasi.

Hal ini dikarenakan karena adanya persaingan yang sangat kompetitif dalam industri perbankan, dan secara umum bank di seluruh dunia menawarkan berbagai produk yang serupa, sehingga nasabah mengevaluasi kinerja bank terutama didasarkan pada kontak pribadi mereka dan interaksi antara karyawan dan nasabah. Sependapat dengan Beerli et al. (2004) dalam industri keuangan seperti perbankan, dimana lingkungan yang kompetitif dan dinamis dan layanan yang ditawarkan sangat kompleks, adalah penting untuk mengenali pentingnya orientasi pelanggan sesuai prinsip-prinsip pemasaran relasional.

Temuan studi ini mendukung pendapat dari Fogli (2006), yang menyatakan bahwa kualitas layanan adalah perspektif konsumen dalam jangka panjang dan merupakan penilaian kognitif, dengan demikian untuk mempertahankan loyalitas, maka organisasi perlu mempertahankan kepuasan konsumen terhadap kualitas jasa yang dia peroleh. Hal ini disebabkan kualitas layanan merupakan evaluasi secara menyeluruh yang dilakukan oleh konsumen dari sejumlah atribut yang terkait dalam layanan (Brady and Cronin, 2001; Clemes J et al., 2008), sehingga kualitas layanan yang baik adalah tergantung sejauh mana persepsi nasabah terhadap kualitas layanan yang diberikan, jika persepsi bertemu atau bahkan melampaui harapan berarti menunjukkan bahwa kualitas jasa yang disampaikan adalah ideal. Sebaliknya jika harapan tidak bertemu dengan persepsi, maka akan dihasilkan evaluasi kualitas layanan yang negatif.

Temuan studi ini mendukung hasil penelitian yang dilakukan oleh Petrick J. Philip (2004); Fullerton and Taylor (2002); Crauna (2002), yang menemukan bahwa kualitas layanan berpengaruh signifikan terhadap loyalitas pelanggan. Hasil beberapa penelitian mengenai service marketing telah membuktikan adanya peran penting dari kualitas jasa dan kepuasan konsumen dalam membentuk minat membeli (Peltier et al., 2002).

\section{Hipotesis 2: Kualitas Layanan $\left(X_{1}\right)$ Berpengaruh Signifikan Terhadap Komitmen Afektif Nasabah Debitur PT. Bank Kalbar di Kalimantan Barat (Y2)}

Hasil pengujian koefisien jalur (Tabel 1) menunjukkan bahwa kualitas layanan berpengaruh signifikan terhadap komitmen afektif dengan arah hubungan positif sebesar 0,286 dengan probabilitas signifikansi (p) sebesar 0,000. Berdasarkan hasil pengujian tersebut, maka dapat disimpulkan bahwa hipotesis ke dua yang menyatakan kualitas layanan berpengaruh signifikan terhadap komitmen afektif nasabah debitur PT. Bank Kalbar di Kalimantan Barat adalah terbukti (diterima).Temuan ini bermakna bahwa nasabah telah menikmati kualitas layanan yang baik dari PT. Bank Kalbar di Kalimantan Barat. 


\section{Jurnal Manajemen Teori dan Terapan Tahun 5. No. 2. Agustus 2012}

Hasil studi ini mengindikasikan bahwa PT. Bank Kalbar telah mampu memberikan kualitas layanan yang baik kepada nasabahnya yang dicerminkan oleh adanya bukti kualitas interaksi, kualitas lingkungan fisik dan kualitas hasil akhir yang diberikan oleh PT. Bank Kalbar mampu memenuhi harapan nasabahnya. Hasil studi ini konsisten dengan hasil penelitian beberapa peneliti yang menguji adanya pengaruh kualitas layanan terhadap komitmen afektif diantaranya adalah Fullerton (2000); Venetis Karin A and Pervez N. Ghauri (2004), Fullerton (2005), Jones Tim et al. (2010), yang menyatakan bahwa persepsi terhadap kualitas layanan akan mempengaruhi komitmen afektif nasabah.

Sedangkan hasil studi ini tidak konsisten dengan hasil penelitian yang dilakukan oleh Beth Davis et al. (2009), yang menyatakan bahwa kualitas layanan tidak berpengaruh pada komitmen afektif. Hal ini disebabkan adanya perbedaan setting dalam penelitian. Studi yang dilakukan saat ini adalah pada nasabah debitur bank sedangkan pada penelitian Beth Davis et al. (2009) dengan setting konsumen retail. Sejalan dengan pendapat Lovelock and Wirtz (2007;33) yang mengemukakan "not all services are like and that differences among services have important implications for customer behavior". Semua jasa tidaklah sama dan perbedaan-perbedaan antar jasa mempunyai implikasi atau pengaruh penting terhadap perilaku konsumennya. Hal ini menunjukkan bahwa dalam penyampaian jasa ke pelanggan, intensitas hubungan antara organisasi jasa yang satu dengan jasa yang lainnya sangat berbeda tergantung dari produk jasa yang disampaikan, karena intensitas hubungan tersebut akan menentukan persepsi pelanggan terhadap jasa yang ditawarkan oleh perusahaan atau organisasi.

\section{Hipotesis 3: Kualitas Layanan $\left(X_{1}\right)$ Berpengaruh Signifikan Terhadap Komitmen Normatif Nasabah Debitur PT. Bank Kalbar di Kalimantan Barat (Y2)}

Hasil pengujian koefisien jalur (Tabel 1) menunjukkan bahwa kualitas layanan berpengaruh signifikan terhadap komitmen normatif dengan arah hubungan positif. Berdasarkan hasil pengujian tersebut, maka dapat disimpulkan bahwa hipotesis keempat yang menyatakan kualitas layanan berpengaruh signifikan terhadap komitmen normatif nasabah debitur PT. Bank Kalbar di Kalimantan Barat adalah terbukti (diterima). Temuan ini bermakna bahwa nasabah telah menikmati kualitas layanan yang baik dari PT. Bank Kalbar di Kalimantan Barat sehingga nasabah tetap mempertahankan hubungan yang berlanjut dengan PT. Bank Kalbar.

Hasil penelitian ini mendukung penelitian yang dilakukan oleh Tim Jones et al. (2010); Ruben Chumpitaz Caceres and Nicholas G. Paporoidamis (2007); Venetis and Ghauri (2004); Fullerton (2000), bahwa kualitas layanan mempengaruhi komitmen normatif. Komitmen normatif adalah dimana pelanggan secara psikologis terikat pada organisasi (Gruen et al., 2000). Kewajiban ini biasanya dikembangkan dari tekanan sosial untuk melakukan dalam suatu cara tertentu atau sesuai dengan standar perilaku tertentu (Meyer and Allen, 1997). Sehingga komitmen normatif nasabah adalah bukti dari adanya emosi yang mentransformasikan perilaku pembelian berulang dan menjadi relationship (hubungaan relasi). Jika nasabah tidak merasakan adanya kedekatan dengan suatu bank, maka hubungan antara nasabah dan karyawan bank tidak memiliki karakteristik suatu hubungan. Ini berati bahwa untuk membuat nasabah selalu ingin manjalin hubungan jangka panjang dengan bank diperlukan usaha yang lebih keras lagi. Bank tidak hanya harus mampu memberi nilai dan benefit lebih untuk membuat nasabah memilih produk dan jasa bank tetapi juga terus menerus melakukan berbagai upaya untuk mempertahankan pelanggan.

Komitmen normatif dapat dipengaruhi oleh upaya-upaya untuk menciptakan rasa kewajiban pada bagian dari konsumen untuk tetap dengan penyedia layanan, baik melalui penggunaan norma-norma untuk perilaku yang sesuai atau dengan menciptakan "kontrak psikologis" 
Nur Afifah

dengan pelanggan dengan mengembangkan hubungan saling menguntungkan di mana konsumen merasa mereka harus menanggapi (misalnya menyediakan layanan ekstra tanpa biaya).

\section{Hipotesis 4: Kualitas Layanan $\left(X_{1}\right)$ Berpengaruh Signifikan Terhadap Komitmen Kontinuan Nasabah Debitur PT. Bank Kalbar di Kalimantan Barat (Y3)}

Hasil pengujian koefisien jalur (Tabel 1) menunjukkan bahwa kualitas layanan berpengaruh signifikan terhadap komitmen kontinuan dengan arah positif. Hal ini terlihat dari koefisien jalur yang bertanda positif sebesar 0,118 dan diperoleh probabilitas signifikansi (p) sebesar 0,004 yang lebih kecil dari taraf signifikansi (a) 0,05, dengan demikian kualitas layanan berpengaruh secara langsung pada komitmen kontinuan.

Hasil studi ini tidak sejalan dengan Venetis Karin A and Pervez N. Ghauri (2004), yang mengatakan bahwa kualitas layanan berpengaruh secara negatif terhadap komitmen kontinuan. Argumentasi logis yang mendasarinya adalah karena adanya perbedaan jasa dalam studi ini. Pada studi yang dilakukan oleh Venetis Karian and Pervez N. Ghauri dilakukan pada perusahaan sektor periklanan sedangkan studi ini dilakukan pada jasa keuangan yaitu perbankan, dengan demikian sangat logis apabila hasil studi ini bertentangan. Adanya perbedaan antara produk manufaktur dengan produk jasa, menyebabkan diperlukan strategi yang berbeda dalam menyampaian jasa dengan layanan yang berkualitas. Hal ini sejalan dengan pendapat Johansson and Olhager (2003) mengatakan sebagai berikut; "We deal with industrial service, which is found at the intersection of manufacturing and service". Terdapat perpotongan (interaksi) antara manufaktur dan jasa dalam industrial service.

Studi ini sejalan dengan penelitian yang dilakukan oleh Fullerton (2005), yang mengatakan bahwa kualitas layanan berpengaruh signifikan terhadap komitmen kontinuan. Argumentasi logis dan rasional diterimanya hipotesis keenam dalam studi ini, terkait dengan karakteristik nasabah pada PT. Bank Kalbar di Kalimantan Barat yang merupakan nasabah debitur dalam hal ini adalah nasabah B2B (business to business) dan dengan tingkat pendidikan yang cukup yaitu paling banyak dengan pendidikan SMA, selain itu nasabah debitur sudah menjadi nasabah debitur PT. Bank Kalbar lebih dari satu tahun adalah jumlah yang terbanyak, jadi suatu hal yang wajar jika nasabah dengan karaketristik tersebut, merupakan pelanggan yang cenderung mempunyai harapan yang tinggi terhadap kualitas layanan yang baik, dikarenakan nasabah sudah bisa membandingkan antara layanan yang diterimanya.

\section{Hipotesis 5: Komitmen Afektif $\left(Y_{1}\right)$ Berpengaruh Signifikan Terhadap Loyalitas Nasabah Debitur PT. Bank Kalbar di Kalimantan Barat $\left(\mathrm{Y}_{4}\right)$.}

Hasil pengujian koefisen jalur (Tabel 1) menunjukkan bahwa komitmen afektif berpengaruh signifikan terhadap loyalitas nasabah dengan arah positif sebesar 0,266 dan diperoleh probabilitas sebesar 0,004 yang lebih kecil dari taraf signifikansi (a) yang ditentukan sebesar 0,05 . Hal ini berarti bahwa hipotesis kelima dalam studi ini yang menyatakan bahwa komitmen afektif berpengaruh signifikan terhadap loyalitas nasabah debitur PT. Bank Kalbar di Kalimantan Barat terbukti kebenarannya (diterima).

Hasil studi konsisten membuktikan adanya pengaruh signifikan komitmen afektif terhadap loyalitas nasabah Bank. Temuan ini bermakna bahwa nasabah telah merasakan kepuasan yang tinggi atas kinerja yang dirasakan dari kredit usaha kecil PT. Bank Kalbar yang menjadi mitra bisnisnya, sehingga kepuasan yang dirasakan nasabah tersebut akan menumbuhkan komitmen afektif pada nasabah yang dapat mengikat mereka untuk tetap mempertahankan hubungan dengan PT. Bank Kalbar di Kalimantan Barat. 


\section{Jurnal Manajemen Teori dan Terapan Tahun 5. No. 2. Agustus 2012}

Hasil studi ini sejalan dengan hasil penelitian yang dilakukan oleh Fullerton Gordon (2005); Josee Bloemerand Gaby Odekerken (2007); Alison M. Dean (2007); Beth Davis Srameck et al. (2009), yang mana hasil studinya menjelaskan bahwa komitmen afektif berpengaruh signifikan terhadap loyalitas nasabah. Hal ini dimungkinkan kesamaan dari obyek penelitian yang dilakukan dalam studi ini yaitu sama-sama melakukan studi pada industri jasa keuangan, sehingga hasil yang ditemukan adalah sama, bahwa komitmen afektif mempengaruhi loyalitas nasabah.

Hasil studi ini tidak sejalan Barbara Cater and Vezna Dabkar (2009) yang menyatakan bahwa komitmen afektif tidak berpengaruh signifikan terhadap loyalitas pelanggan. Hal ini bisa saja terjadi dikarenakan adanya perbedaan dari jenis jasa yang dilakukan dalam studi ini. Jasa dalam studi Barbara Cater and Vezna Dabkar (2009) adalah jasa layanan bisnis professional, sedangkan jasa dalam studi ini adalah jasa keuangan yaitu perbankan, sehingga adanya perbedaan antar jasa, mengakibatkan pemahaman dan persepsi konsumen terhadap service quality (kualitas layanan) dalam bisnis jasa pun akan berbeda.

\section{Hipotesis 6 : Komitmen Normatif $\left(Y_{2}\right)$ Berpengaruh Signifikan Terhadap Loyalitas Nasabah Debitur PT. Bank Kalbar di Kalimantan Barat $\left(\mathrm{Y}_{4}\right)$.}

Hasil pengujian koefisen jalur (Tabel 1) menunjukkan bahwa pengaruh komitmen normatif terhadap loyalitas nasabah memiliki koefisien jalur sebesar 0,056 dan diperoleh probabilitas sebesar 0,045 yang lebih kecil dari taraf signifikansi (a) yang ditentukan sebesar 0,05. Hal ini menunjukkan bahwa hipotesis ke enam yang menyatakan komitmen normatif berpengaruh signifikan terhadap loyalitas nasabah debitur PT. Bank Kalbar terbukti kebenarannya (diterima).

Hasil studi ini tidak sejalan dengan hasil penelitian yang dilakukan oleh Barbara Cater and Vesna Zabkar (2009), yang menyatakan bahwa komitmen normatif tidak berpengaruh signifikan terhadap loyalitas nasabah. Tetapi studi ini sejalan dengan hasil penelitian yang dilakukan oleh Tim Jones et al. (2010); Josee Bloener and Gaby Odekerken Schroder (2007); Fullerton (2000), tidak sejalannya hasil studi ini, dikarenakan hasil penelitian yang dilakukan oleh Barbara Cater and Vesna Zabkar (2009) dengan setting pada perusahaan layanan bisnis professional. Hal ini sependapat dengan Lovelock and Wirt (2007;33), yang mengemukakan "not all services are a like and that differences among services have important implications for customer behavior". Semua jasa tidaklah sama dan perbedaan-perbedaan antar jasa mempunyai implikasi atau pengaruh penting terhadap perilaku konsumennya. Hal ini menunjukkan bahwa dalam penyampaian jasa ke pelanggan, intensitas hubungan antara organisasi jasa yang satu dengan jasa yang lainnya sangat berbeda tergantung dari produk jasa yang disampaikan, karena intensitas hubungan tersebut akan menentukan persepsi pelanggan terhadap jasa yang ditawarkan oleh perusahaan jasa.

Akan tetapi hasil studi ini, juga menunjukkan bahwa pengaruh komitmen normatif terhadap loyalitas nasabah memiliki pengaruh yang paling kecil, diantara 7 (tujuh) hipotesis yang diajukan dalam studi ini. Hal ini harus menjadi perhatian bagi PT. Bank Kalbar, dikarenakan apabila komitmen normatif yang terbentuk pada diri nasabah semakin rendah maka akan mempengaruhi rendahnya loyalitas nasabah karena persaingan antar bank saat ini sangat ketat, sehingga untuk mengantisipasi nasabah debitur PT. Bank Kalbar tidak berpindah ke bank lainnya dan tetap memiliki komitmen normatif yang tinggi untuk tetap komit dalam hubungan, maka layanan tambahan yang saat ini sudah diberikan oleh PT. Bank Kalbar perlu ditingkatkan lagi sehingga memberikan manfaat bagi nasabah debitur. Hal ini sependapat dengan Tim Jones et al. (2010), yang menyatakan bahwa komitmen normatif yang sudah tumbuh dalam diri nasabah belum tentu berpengaruh terhadap loyalitas nasabah apabila perusahaan 
Nur Afifah

perbankan tidak memberikan layanan tambahan yang membuat nasabah tetap bertahan dalam perusahaan perbankan.

\section{Hipotesis 7 : Komitmen Kontinuan $\left(Y_{3}\right)$ Berpengaruh Signifikan Terhadap Loyalitas Nasabah Debitur PT. Bank Kalbar di Kalimantan Barat $\left(Y_{4}\right)$.}

Hasil pengujian koefisien jalur (Tabel 1) menunjukkan bahwa komitmen kontinuan berpengaruh signifikan terhadap loyalitas nasabah memiliki koefisien jalur sebesar 0,310 dan diperoleh probabilitas signifikansi ( $p$ ) sebesar 0,000 yang lebih kecil dari taraf signifikansi (a) yang ditentukan sebesar 0,05. Hal ini berarti bahwa hipotesis ke tujuh dalam studi ini yang menyatakan bahwa komitmen kontinuan berpengaruh signifikan terhadap loyalitas nasabah terbukti (diterima). Temuan ini bermakna bahwa nasabah debitur PT. Bank Kalbar telah memiliki ikatan psikologis dengan PT. Bank Kalbar sehingga membuat nasabah tetap menjadi bagian dari organisasi PT. Bank Kalbar dan tidak akan berpindah dari bank lain, yang dihubungkan dengan biaya yang dikeluarkan jika nasabah mengakhiri hubungan dengan PT. Bank Kalbar di Kalimantan Barat.

Hasil studi ini tidak sejalan dengan hasil studi yang dilakuakan oleh Josee Bloemer and Gaby Odekerken (2007); Barbara Cater and Vesna Dabkar (2009) yang menyatakan bahwa komitmen kontinuan tidak berpengaruh signifikan terhadap loyalitas. Akan tetapi studi ini sejalan dengan Jones Tim et al. (2010) dan Fullerton (2005).

\section{SIMPULAN}

Beberapa kesimpulan yang dapat disajikan dalam penelitian ini adalah: 1. Terdapat pengaruh yang signifikan dari kualitas layanan terhadap loyalitas nasabah dengan arah hubungan positif, 2. Kualitas layanan berpengaruh signifikan terhadap komitmen afektif dengan arah hubungan positif, 3. Kualitas layanan berpengaruh signifikan terhadap komitmen normatif dengan arah hubungan positif, 4. Kualitas layanan berpengaruh signifikan terhadap komitmen kontinuan dengan arah hubungan positif, 5. Komitmen afektif berpengaruh signifikan terhadap loyalitas nasabah dengan arah hubungan positif, 6. Komitmen normatif berpengaruh signifikan terhadap loyalitas nasabah dengan arah hubungan positif, 7. Komitmen kontinuan berpengaruh signifikan terhadap loyalitas nasabah dengan arah hubungan positif.

Kontribusi penelitian terhadap pengembangan ilmu pengetahuan ditunjukkan melalui jalur yang diuji yang menunjukkan bahwa secara keseluruhan hubungan yang diuji dalam 7 (tujuh) hipotesis menunjukkan hubungan yang signifikan dan positif. Membuktikan bahwa model dalam studi ini merupakan model pemasaran relasi (marketing relationship) yang mampu membangun loyalitas nasabah dengan bank. Studi ini telah membuktikan keterkaitan antara kosep kualitas layanan dengan pemasaran relasi. Sejalan dengan pendapat (Cronin and Taylor, 1992; Zeithaml et al., 1996). Selanjutnya hasil studi sejalan dengan Caruana (2002), yang menyatakan bahwa kualitas layanan memberikan pengaruh yang signifikan terhadap loyalitas, baik secara langsung maupun tidak langsung melalui kepuasan. Selanjutnya hasil studi sejalan dengan (Gundlach et al., 1995; Morganand Hunt, 1994; Berry and Parasuraman, 1991), yang menyatakan pelanggan komitmen dipandang sebagai faktor kunci dalam retensi pelanggan dan loyalitas. Dengan demikian memotivasi nasabah untuk melanjutkan hubungan juga berbeda-beda, oleh karena itu komitmen dalam hal ini berhubungan dengan komitmen afektif, komitmen normatif serta komitmen kontinuan, sejalan dengan (Tim Jones et al., 2010; Josess Bloemer and Gaby Odekerken, 2007; Bansal et al., 2004). Selain itu, kontribusi hasil studi memberikan informasi kepada manajemen PT. Bank Kalbar bahwa kualitas layanan mampu memberikan kontribusi terhadap terciptanya loyalitas nasabah debitur PT. Bank Kalbar di Kalimantan Barat melalui terciptanya kepuasan nasabah, komitmen afektif, komitmen normatif dan komitmen kontinuan. 


\section{Jurnal Manajemen Teori dan Terapan Tahun 5. No. 2. Agustus 2012}

\section{DAFTAR PUSTAKA}

Alison M. Dean, 2007. The Impact of The Customer Orientation of Call Center Employess on Customers Affective Commitment and Loyalty. Journal of Service Research, Vol. 10. No. 2, November.

Allen, N.J. and Meyer, J.P. 1990. The Measurement and Antecedents of affective, continuence, and normative commitment to the organizations. Journal of occupational Psychology, Vol. 63. pp. 1 -8.

1994. Affective, Continuance, and Normative Commitment to the Organization: An Examination of Construct Validity. Journal of Vocational Behavior, Vol. 49, pp. $252-276$

Bagozzi, Richard P, 1993. On the Neglect of Volition in Consumer Research: A Critique and Proposal. Psychology and Marketing, 10 (May/june), pp. 215-237.

Bansal, Harvir and Shirley Taylor, 1999. The Service Switching Model (SSM): A Model of Switching Behavior in Services Industries, Journal of service Research, 2 (2), pp. 200-218.

Bansal, H., Irving, G. and Taylor, S., 2004. A Three-Component Model of Customer Commitment to Service Providers. Journal of The Academy of Marketing Science, Vol. 32, No. 3, pp. 234-250.

Beerli, A., Martin, J. D., and Quintana, A, 2004. A Model of Customer Loyalty in the Ratail Banking Market. European Journal of Marketing, Vol. 38, pp. 253-275.

Bitner, Marry Jo, 1990. Building Service Relationship: it's About Promises. Journal of the Academy of Marketing Science, 23 (fall), 264-251.

Bloemer Josee, and Gaby Odekerken-Schroder, 2007. The Psychological Antecedents of Enduring Customer Relationship: An Empirical Study in a Bank setting. Journal of Relationship Marketing, Vol. 6 (1), pp. 21- 43.

Brady, Michael K., and J. Joseph Cronin, 2001. Some Thought on Conceptualizing Perceived Service Quality A Hierarchical Approach. Journal of Marketing, Vol 63- 34- 39.

Caruana Albert, 2002. Service Loyalty The Effects of Service Quality and The Mediating Role of Customer Satisfaction. European Journal of Marketing, Vol. 36 No.7/8 pp. $811-828$.

Cater Barbara and Vesna Zabkar, 2009. Antecedent and Consequences of Commitment in Marketing Research Sevices: The Client's Perspective. Journal Industrial Marketing Management, Vol. 38, pp. 785-797.

Cronin Jr, J. Joseph J., and Steven A. Taylor, 1992. Measuring Service Quality: A Reexamination and Extention. Journal of Marketing, Vol. 56 (July), pp. $55-68$.

Davis Beth-Sramerk, Cornelia Droge. John T. Mentzer and Matthew B. Myers, 2009. Creating Commitment and Loyalty Behavior Among Retailers: What are the Roles of Service Quality and Satisfaction. Journal of the Academy Marketing Science, Vol. 37, pp. 440454.

Dean, M. Alison, 2007. The Impact of The Customer Orinetation of Call Center Employees on Customers Affective Commitment and Loyalty, Journal of Academy of Marketing Science, Vol. 10. No. 2, pp. 161-173.

Doney, Patricia and Joseph Cannon, 1997. An Examination of The nature of Trust in Buyer-Seller Relationships, Journal of Marketing, Vol. 51, pp. 35-51.

Farrel. Andrew, Anne Souchaon and Geoffery Durde, 2001. Service Quality Enhacncement: The Role of Employees Service Behaviours: http: www. abs.aston.ac.uk.

Fournier, Susan. Susan Dobscha, and David Mick, 1998. Preventing the Premature Death of Relationship Marketing, Harvad Business Review, January- February, 43 - 51

Fullerton and Taylor, 2000. Waiting for Service: Perceptions Management of the Wait Experience. In T. Swartz and D. Lacobucci (Eds), The handbook of Services Marketing and Management, pp. 171-190. Thousand Oaks, CA: Sage Publications. 
Nur Afifah

Fullerton and Taylor Shirley, 2002. Mediating, Interactive and Non-Linear Effect in Service Quality and Satisfaction With Service Research. Canadian Journal of Administrative Science, Vol. 19. No. 2: $124-136$.

Fullerton, 2000. The Role of Commitment in Service Relationship. Thesis Submited to School of Business, Doctor of Philosophy Queen's University Kingston, Ontario, Canada, April.

Fullerton, 2004. When Does Commitment Lead to Loyalty. Journal of Service Research, Vol 5, May. pp $333-343$.

Fullerton, 2005. The Service Quality - Loyalty Relationship in Retail Services: Does Comitment Matter. Journal of Retailing and Customer Services 12, pp. $99-111$.

Garbarino, Ellen, Mark S. Johnson, 1999. The Different Roles of Satisfaction, Trust, and Commitment Customer Relationship. Journal of marketing, Vol. 63. April, pp.70-87.

Gilliand, D., Bello, D, 2002. The Two Sides to Attitudinal Commitment: The effect of Calculative and Loyalty Commitment on Enforcement Mechanism in Distribution Channels, Journal of Marketing, Vol. 63, pp. 70- 87.

Gilmore, JH and Pine B. II, 2002. Customer Experinece Places: The New Offering Frontier Strategy and Leadhership, 30, pp. 4-11.

Gronroos. C, 1990. A Service Relationship Approach to Marketing in Service Contacts: The Marketing and Organizational Behavior Interface. Journal of Business Research, Vol. 20: 3 $-11$.

Gruen, Thomas W., John O. Summers, and Frank Acito, 2000. Relationship Marketing Activities, Commitment, dan Membership Behaviors in Profesional Associations. Journal of Marketing, 64 (july), 34-49.

Gundlach, G., Achrol, R., Mentzer, J., 1995. The Structure of Commitment in Exchange, Journal of Marketing, Vol. 59, pp. $78-92$.

Handelman, Jay and Stephen Arnold, 1999. The Role of Marketing Actions with a Social Dimension: Appeals to The Institutional Environment, Journal of Marketing, Vol. 63, pp, 3348.

Harrison-Walker, J, 2001. The Measurement of Word-of-Mounth Communication and an Investigation of Service Quality and Customer Commitment as Potential Antecedents, Journal of Service Research, Vol. 4, pp. 60-75.

Heide, J. and John, G, 1992. Do Norms Matter in Marketing Relationship?, Journal of Marketing, Vol. 56. No. 2, pp. 32-34.

Henning- Thurau. T. and U. Hansen, 2000. Relationship Marketing: Some Reflections on the Statethe-art of the Relational Concept," In T. Henning-Thurau and Hansen (Eds). Relationship Marketing: Gaining Competitive Advantage through Customer

Johns, N., Lee-Ross, D., and Ingram, H, 1997. A Study of Service Quality in Small Hotels and Guesthouses. Progress in Tourism and Hospitality Research, Vol. 3, pp. 351-363.

Johansson, Pontus, and Olhager Jan, 2003. Industrial Service Profiling: Matching Service Offering and Processes. International Journal of Departement of Production Economics, Vol. 89, pp. 309-320.

Jones Tim, Gavin L., Foc, 2010. Service Customer Comitment and Response. Journal of Service Marketing, 24/1 (2010) 16- 28.

Lemke Fred, Moira Clark and High Wilson, 2010. Customer Experience Quality: an Exploration in Business and Consumer Contexts Using Repertory grid Technique. Journal of The Academy Marketing Science, 7 September.

Liu, C., Marchewka, Jack T., Lu, J. and Yu, Chun-Sheng, 2003. Beyond Concern -A Privacy- TrustBehavioral Intention Model of Electronic Commerce. Information and Management, Vol. 42. Issue 1 (Desember), pp. $127-142$.

Lovelock, and Jochen Wirtz, 2007. Service Marketing : People, Technology. Strategy, Fithh Edition. International Edition: Pearson Education International and Prentice Hall. 


\section{Jurnal Manajemen Teori dan Terapan Tahun 5. No. 2. Agustus 2012}

Mathieu, John and Dennis Schoorman, 1992. Predicting Participation and Production Outcomes Through a Two-Dimensional Model of Organizational Commitment, Academy of Management Journal, Vol. 35, pp. 671-684.

Meyer and Natalie Allen, 1997. Commitment in The Work-Palce: Theory, Research and Application. Thousand Oaks, CA: Sage Publications.

Morgan, Robert M. and Shelby D. Hunt, 1994. The Commitment-Trust Theory of Relationship Marketing. Journal of Marketing, Vol. 58 No. 3. Pp. $20-38$.

O'Reilly, Charles and Jennifer Chatman, 1986. Organizational Commitment and Psychological Attachment: The Effects of Complience, Identification and Internalization on Prosocial Behavior, Journal of Applied Psychology, Vol. 71, pp. 492-299.

Parasuraman, A., Valerie A. Zethaml, and Leonard I. Berry, 1988. SERVQUAL A Multi- item Scale for Measuring Consumer Perceptions of service Quality. Journal of Retailing, Vol. 65 (1) : $12-36$

Peltier, James W., John A Schibrowsky, Christopher R Cochran, 2002. Patient Loyalty That Last a Lifetime. Marketing Health Service, Vol. 22 (Summer), pp. 2 - 9.

Rosen, L. D. Karwan, K.R. Scribner, L.L, 2003. Service Quality Measurement and the Disconfirmation Model: Taking Care in Interpretation. Journal Total Quality Management, Vol. 14, No. 1, pp.3-14

Ruben Chumpitaz, Caceresand Nicholas G and Paparoidamis, 2007. Service Quality, Relationship Satisfaction, Trust, Commitment and Business- to- Business Loyalty. European Journal of Marketing, Vol. 41. No. 7/8.

Siddiai Kazi Omar, 201 1. Interrelations Between Service Quality Attributes, Customer Satisfaction and Customer Loyalty in the Retail banking Sector in Bangladesh.

Slater, Stanley F., 1997. Developing a Customer Value-Based Theory of Firm. Journal of The Academy of Marketing Science, Vol. 25. Pp. $162-167$.

Sudhahar J. Clemet. D. Israel and M. Selvam, 2006. Service Quality Measurement in Indian Retail Banking Sector: CA Approach. Journal of Applied Sciences, Vol. 6, pp. 2377-2385.

Van der Wiele, T. Boselie, P. Hesselink, M, 2002. Empirical Evidence for the Relationship Between Customer Satisfaction and Business Performance. Journal Managing Service Quality, Vol. 12, No. 3 pp.184-19.

Vilares, M.J. and Coehlo, P.S, 2003. The employee-customer satisfaction chain in the ESCl model. European Journal of Marketing, Vol. 37, No. 11/12, pp. 1703-1722.

Voss, C. Roth, A.V. Rosenzweig, E.D. Blackmon, K. Chase, R.B, 2004. A Tale of Two Countries Conservatism, Service Quality, and Feedback on Customer Satisfaction. Journal of Service Research, Vol 6, No 3 pp. 212-23

Voss, C. Tsikritis, N. Funk, B. Yarrow, D. Owen, J, 2004. Managerial Choice and Performance in Service Management a Comparison of Private Sector Organisations with Further Education Colleges', London Business school OTM Working Paper No 04-020, date 200406-01.

Venetis, Karim and Pervez N. Gauri, 2004. Service Quality and Customer Retention:Building Longterm Relationships. Europen Journal of Marketing, Vol.38, No.1 1/12,pp. 1577-1598.

Zeithaml, Valerie A., Leonard L. Berry, and Parasuraman, A, 1996. The Bahavioral Consequences of Service Quality, nature and Determinants of Customer Expectations of Service. Journal of marketing, Vol. 60 (April). Pp. 31-46.

and Bitner jo Mary, 1996. Service Marketing, New York:McGraw-Hill Company.

Valerie and Mary Jo Bitner, 2003. Service Quality, Profitability, and the Economic Worth of Customers: What We Know and What We Need to Lerans. Journal of the Academy of Marketing Science, Vol. 28 No. 1, pp. $67-85$. 
Nur Afifah 